\title{
Demography and Aging
}

\author{
François Höpflinger
}

\begin{abstract}
During the last twenty years, sociological analysis has improved our understanding of the dynamic interrelationships between demographic aging and changes in individual aging processes, particularly by looking in more detail at structural and cohort changes in the life situation of the elderly population. Sociological research has provided particularly fruitful contributions on the impact of demographic aging (low fertility rates combined with increased life expectancy) on intergenerational relationships. While research on demographic aging and individual aging has made much progress, public perceptions and political discourses are still dominated by deficit-oriented and simplified views of demographic aging (also due to the fact that demographic aging is mostly measured by using obsolete chronological age definitions).
\end{abstract}

Keywords: Demographic aging, individual aging, longevity, intergenerational relationship

\section{Introductory Observations}

Low fertility rates and high life expectancy have resulted in strong demographic aging. In many European countries, this development has been reinforced by the aging of large cohorts of men and women born after World War II who themselves had few children (baby boomers). A substantial part of demographic and aging research during the last twenty years has been purely descriptive. This is particularly true for reports on demographic aging that contain an abundance of detailed statistical data but lack theoretical depth. The present review on the development of research on demography and aging in German-speaking regions concentrates on selected publications that link empirical and theoretical approaches or at least include innovative conceptual ideas.

In political discourses and media presentations, demographic aging is mostly negatively perceived as an actual or emerging social problem, resulting in, for example, massively higher health costs, huge deficits of social support systems, distressed care systems, or intergenerational conflicts. Such negative perceptions of demographic aging are reinforced by deficit-oriented images of old age. A substantial part of the sociological analysis of demographic aging and individual aging during the last twenty years has concentrated on refuting those purely negative interpretations of demographic aging or at least on interpreting demographic processes within a broader societal frame of reference. A good and widely read example of this approach is the book by Anton Amann (2004), which criticizes modern aging myths of an emerging 
war between generations, a collapsing care system, or aging as a significant brake on innovation.

This article is organized as follows: Sections 2 and 3 discuss the place of sociology in demographic and aging research, with special reference to a new understanding of demographic aging in rapidly changing societies. Section 4 addresses relevant sociological topics on demography and aging (for example, an aging workforce, the impact of demographic aging on social structures and intergenerational relationships). The article closes with some general observations on the current state of sociological research on demography and aging.

\section{Demographic and Aging Research-Sociological Contributions}

When looking at the contribution of sociology in German-speaking countries to the topics of demography and aging, we have to take into account, on the one hand, that demographic and aging research is-ideally-multidisciplinary or even transdisciplinary. In many ways, sociological approaches are linked with socio-economic and socio-political fields of research, for example, when considering the effects of demographic aging on social policies or health systems. On the other hand, some sociological concepts (concepts of lifestyles, for instance) are widely used within demographic and aging research, often by researchers from other disciplines (statistics, economics, psychology, or geriatric medicine). Similar to what can be observed in regard to other relevant societal topics, here too sociological theories have been successfully integrated but often outside of sociological work.

The main impact of sociological approaches has been to link demographic processes and social structures in a differentiated frame of reference. A widely perceived introduction and analysis of demographic aging was published by Peter Schimany (2003). Besides providing an introduction to demographic methods and an analysis of the social consequences of demographic aging on labor markets and systems of social security, he argued for a sociology of aging that systematically analyzes socio-cultural changes of individual aging within a demographically aging society (a dimension that is mostly neglected in purely demographic research). A current and excellent overview of the German sociology of demography is provided by the reader edited by Yasemin Niephaus, Michaela Kreyenfeld, and Reinhold Sackmann (2016), which discusses nearly all relevant demographic topics within an open-minded but clearly sociological frame of reference. One of the main conclusions of their review is that demographic processes are rapidly changing as social conditions and individual aging processes are affected by strong cohort and period effects. 


\section{A New Understanding of Aging-Cohort Effects and Structural Changes of Aging Processes}

In recent decades, demographic research and aging research have developed a more critical view of chronological age. Yet, chronological age measurements are still dominant in demographic statistics-particularly in regard to demographic aging. Demographic aging is traditionally measured by comparing the number of people aged 65 and older to the total number of persons within a given region and through dependency ratios that relate the number of people over 64 to those aged 20-64. This has not changed in the last twenty years despite increasing methodological criticism. A majority of demographic analyses-in Germany and internationally-does not, or at least only partially, take account of changing concepts of age and aging, even as new, dynamic indicators for measuring demographic aging have been developed (Sanderson and Scherbov, 2007). In aging research too (when analyzing individual aging processes or the lifestyles of older men and women), it has become more and more evident that chronological age itself is a variable that explains surprisingly little-at least until the very late phases of life. Other variables (from gender, social milieu, health behavior, functional health to subjective age or birth cohort) are more relevant. This is one of the main reasons why new concepts of aging have been developed (for example, active aging or healthy aging), reflecting an understanding of individual aging as a multidimensional and multidirectional process, a process that, even among men and women at the highest ages, is strongly related to social and psychological factors and involves significant cohort effects.

In modern and dynamic societies, demographic aging is happening at the same time that cohort changes in health behavior and the lifestyles of the elderly population are becoming more salient and new models of aging (such as active, productive, or creative aging or anti-aging medicine) are emerging, particularly among the more affluent elderly. Today's elderly are aging differently than earlier generations. As result of better education, new forms of family formation (and dissolution), and changing socio-economic conditions during the last few decades, the present generations of elderly generally display a more active attitude toward life after retirement. The lifestyles of today's cohorts of retired men and women are clearly evolving in the direction of more active lifestyles, at least among healthy and affluent European retirees. An interesting discussion of such structural changes-linking the lifestyles of new generations of retirees in Germany with the youth movements of the 1960s-has been published by Fred Karl (2012). The German aging surveys (from 1996 onwards) show that we can observe significant changes in life perspectives and lifestyles of the elderly population in nearly all social dimensions (Motel-Klingebiel et al., 2010; Mahne et al., 2017; Tesch-Römer et al., 2006).

Cohort and structural changes of individual aging have resulted in sociologically important conceptual developments: First, deficit-oriented concepts of aging have been replaced by concepts of active or even successful aging (for an overview, see 
Klott, 2014; Kolland and Wanka, 2014). Individual aging is no longer perceived as a process to be endured passively but as one that can be formed and shaped actively. A radical consequence of an active attitude towards aging is the emergence of antiaging medicine to prevent or at least slow down biological aging. Second, subjective and chronological age differ in significant ways as new generations define themselves as being much younger than their chronological age. Many retired persons define themselves as not being "really old" as long as they live at home without requiring extensive help (Graefe et al., 2011).

A trend toward a more 'youthful' life after retirement can be interpreted as an important countervailing factor to traditional concepts of demographic aging. When men and women at age 70 have lifestyles that correspond to the lifestyles of much younger generations, demographic aging does not result in a socially or culturally aging society. At the same time, new models of individual aging contribute to a greater heterogeneity or inequality of aging processes within and between European countries, as primarily affluent elderly in affluent European regions profit from more active retirement and longer healthy life expectancy.

Over the last few decades, the distinction of at least two different types of older persons has become popular in aging research. The traditional notion of age bifurcates between a new and rapidly expanding population of healthy and independent 'youngold' (third age) and a frail or dependent population of 'old-old' (fourth age). ${ }^{1}$ The most important German study of life at advanced ages in the last twenty years has been the Berlin Aging Study, an interdisciplinary longitudinal research study (Mayer and Baltes, 1996; Lindenberger et al., 2010).

While the beginning of the third age is characterized by a socially crucial transition (retirement), the fourth age remains conceptually more ambivalent, as the start of the fourth age is not structurally defined. The concept of fourth age refers either to very old people aged over 80 or alternatively to frail or dependent old persons. The German gerontologist Ludwig Amrhein (2013) proposed the interesting thesis that the social upgrading of the third age has proceeded to a social devaluation of the fourth age. While the 'young-old' are perceived as active subjects, the 'old-old' are still primarily seen as passive objects of help and care. In a certain sense, the now popular distinction of 'young-old' versus 'old-old' reflects the societal difficulties of dealing with changing aging processes by using traditional concepts of age. A good and critical reflection on the (heuristic) construct of the 'young-old' has been provided by Sylke van Dyk and Stefan Lessenich (2009).

1 The term 'young-old' was first used by the American gerontologist Bernice Neugarten (1974) and later developed into an elaborate theory of a third age by Peter Laslett (1989). 


\section{Demography and Aging-Relevant Sociological Topics}

Demographic aging and individual aging are processes that affect practically all societal dimensions. In this section, I concentrate on select topics in which-at least in my opinion-sociological analysis has contributed to a new understanding of the societal consequences of demographic and aging processes.

\subsection{Aging workforce}

A hot topic over the last twenty years has been the consequences of an aging workforce on the labor market and enterprises (Aulenbacher/Grubner, WORK AND LABOR, this volume). This topic has generated a vast number of national and international reports and discussion papers (with actually only a very limited number of theoretically integrated approaches to the issue of older workers). From an economic point of view, there has been a broad discussion of questions related to decreasing economic productivity and less innovation as a consequence of a growing proportion of elderly workers. As far as consolidated results are available, the effects of an aging workforce on productivity seem to be very limited (Düzgun et al., 2006). Human relations approaches and psychological experts have emphasized the risks of decreasing work ability among older workers and discussed ways to improve their work motivation and ability (for example, Ilmarinen, 1999). Sociological research has primarily focused on two other aspects: first, changes in processes of retirement (for example, early retirement or flexible forms of retirement), often by comparing retirement decisions in different countries or occupations (Behrend, 2001; Kohli et al., 1991); second, the working situation, social status, and risk factors of different groups of older workers and employees (Clemens, 2001; Clemens et al., 2005; Naegele, 1992). In the latter context, questions of ageism and age-related discrimination in the labor market have been discussed in detail (for a good overview, see Brauer and Clemens, 2010).

A relatively new approach in the context of an aging workforce has been to look at intergenerational challenges within labor markets or at intergenerational exchanges in the workplace (George and Struck, 2000; Sackmann, 1998). One main conclusion of such approaches is that intergenerational differences (for example, regarding innovation or issues of work-life balance) are less determined by age but by differences in life stages and working biographies. (Huinink/Hollstein, LIFE COURSE, this volume)

Generally, the heterogeneity of workers and employees aged over fifty (who differ strongly according to educational attainment as well as actual and past occupational activities, status, and income) makes it difficult to arrive at firm conclusions, and rapid 
changes in labor markets and workplaces have generally reduced the practical impact of sociological research. ${ }^{2}$

\subsection{Aging and decreasing population combined}

Since the 1990s a new demographic phenomenon has emerged in some German regions: the concurrence of demographic aging and a decreasing population. Questions of observed or expected population decline have gained greater attention. And in fact, for the first time in history, populations are decreasing not because of war or disease, but as a process occurring in peaceful and relatively affluent societies. Internationally, Japan and Germany are seen as the front-runners in such developments (Coulmas and Lützeler, 2011). In general, a decreasing population is viewed as an indicator of economic stagnation or lack of social attractiveness. However, as regional analyses illustrate, a decreasing population can be the result of very different social and demographic factors (as diverse as emigration of young people from peripheral regions and functional differentiation between the places of work and residence; Bucher and Mai, 2006). In any case, demographic aging along with a declining number of inhabitants has many political and administrative consequences (Bartl, 2011). From a sociological perspective, the main challenge is that a decreasing population has different social, economic, and political impacts than an increasing population. As the sociologist Franz-Xaver Kaufmann $(2005)^{3}$ observed, there is a structural lack of solutions for the problems of negative population growth in modern societies, that is, in societies that are bent on solving all problems via growth (115). He postulates that-contrary to population growth, which leads to stimulating diversity-depopulation is associated with consolidating or even intensifying social and regional inequalities.

\subsection{Longevity and social structures}

While the demographic and social effects of low fertility rates on the age distribution of a population have been intensively analyzed, the second dimension of demographic aging-increasing life expectancy-has been less discussed. In the context of increasing life expectancy, one has to mention the internationally widely cited article by Jim Oeppen and James Vaupel (2002), which at least partly originated within Germany (Max Planck Institute for Demographic Research in Rostock). Their research indicates

2 Under rapidly changing conditions, the impact of large research studies is limited by the fact that the results of a given study are quickly perceived as obsolete and no longer relevant to the actual situation.

3 Franz-Xaver Kaufmann can be seen as a pioneer of sociological approaches to demographic aging as his first publication on the topic dates back to 1960 (Kaufmann, 1960). 
a surprisingly linear increase in life expectancy over the last one hundred and fifty years when we look not at single countries but at those countries that have experienced the highest average life expectancy during a given time period.

What is even more interesting from a sociological perspective is the effects of increased life expectancy on life phases and social structures. One of the most elaborate German works on the relationships between increased life expectancy and social structures in modern societies is the analysis by Helga Pelizäus-Hoffmeister (2011). Drawing on an earlier paper by Martin Kohli (1985), she reflects on, from a sociostructural perspective, how high life expectancy is interrelated with important dimensions of modern life, such as career planning, concepts of lifelong learning, saving for retirement, and so forth. In line with other sociologists (e.g., Höpflinger, 2016), she argues that elaborate and culturally accepted forms of individualism are only possible in societies with high and secure life expectancy.

In the last twenty years, international efforts have been made to develop a valid and comparable indicator of the quality of a longer lifespan. Indicators that seek to capture the extent to which individuals can expect to live a healthy, disability-free, or active life actually try to answer a very important question: To what extent is increasing longevity just an extension of years lived in ill health or in functional dependency, or to what degree does it involve a longer life in good health? Of particular interest from a sociological perspective are, however, primarily observations and analyses that inquire into the social inequalities of morbidity risks. One of the first German sociologists to analyze social determinants of active life expectancy was Thomas Klein (1999). He examined not only the traditional social inequalities in regard to life expectancy in general but also social inequalities in active life expectancy (relating to gender, educational attainment, lifestyles, etc.). His approach has gained increased importance both in discussing social inequalities and in measuring the quality of a longer lifespan. Methodological difficulties in measuring health status in a lifespan perspective have yielded inconsistent results, particularly regarding healthy and disability-free life expectancy, but large social inequalities in the quality of longer life expectancies remain obvious (for a recent overview of concepts, methods, and results, see Unger, 2016) (Otte/Boehle/Kunißen, SOCIAL INEQUALITIES-EMPIRICAL FOCUS, this volume).

\subsection{Demographic aging and intergenerational relationships}

Low fertility rates and high life expectancy have substantially changed intergenerational family structures, reducing the number of horizontal family ties and increasing the shared lifespan of family members (adult children and parents, grandchildren and grandparents). From the late 1990s onwards these structural changes-and their impact on intergenerational relationships-have been innovatively analyzed and discussed among German researchers (Lauterbach, 1995; Grünheid and Scharein, 2011). Late family formation in Germany, however, has resulted in families with four living 
generations being less widespread than in other countries and families with three living generations being the dominant model (Puur et al., 2011). The emergence of new intergenerational structures has given rise to new social discourses on adult children and aging parents, for example, the powerful image of the middle generation being a 'sandwich generation', a term coined to describe a generation that has to invest both in the youngest and the oldest generations. At the same time, a second work-family conflict has gained importance: paid work and unpaid care for old family members. One of the first and still one of the best theoretical reflections on conflicts between family care and work responsibilities was published by Ursula Dallinger (1998). More generally, Marc Szydlik (2000; 2016) developed a widely cited theoretical model of intergenerational relationships and intergenerational solidarity. He linked the needs and the opportunity structures of adult children and aging parents with dimensions of family structures and cultural-contextual dimensions to describe intergenerational solidarity in modern societies over the lifespan of children and parents.

At least in my view, the topic of adult children and aging parents in dynamic but demographically aging societies is one of the research areas where sociology has made the most theoretical and empirical progress. This is an area where German researchers have been at the forefront of novel approaches. ${ }^{4}$ Since 2004, a large and ongoing European survey (Survey of Health, Ageing and Retirement in Europe; SHARE)-coordinated by the Munich Center for the Economics of Aging and the Max Planck Institute for Social Law and Social Policy in Munich-has made it possible to analyze intergenerational relationships in later life in more detail on the basis of theoretically, integrated multi-level analyses (persons, households, intergenerational dyads, family structures of two generations, and contextual factors). It has facilitated analyzing in more detail the multi-local character of later family phases-as discussed, for example, by Wolfgang Lauterbach (1998)-for different countries, emphasizing intensive family ties even when family members are not living in the same household or building (Isengard, 2013; 2018). One central consequence of such research is that household statistics are not, or at least no longer, very important for describing social relationships in aging societies of today (Konietzka/Feldhaus/ Kreyenfeld/Trappe, FAMILIY AND INTIMATE RELATIONSHIPS, this volume).

A group of younger sociologists have used SHARE data to link demographic aging and family variables and have thereby successfully described important determinants of intergenerational help, care, and financial transfers within different European countries (Brandt, 2009; Brandt et al., 2009; Deindl, 2011; Deindl and Brandt, 2011; Haberkern, 2009). Their multi-level analyses illustrate the impact of opportunity structures (for example, living nearby or not), of the needs of younger and older generations, and of family structures on intergenerational relationships in societies in

4 An interesting but still not fully researched aspect of longevity of parents is that new generations of women and men experience old age often twice or thrice: first, the aging of grandparents; second, the aging of parents; and third, their own aging (and the aging of older family members is often experienced as 'shadowing one's own future'). 
which many adult children are confronted with aging parents. Two general findings of those studies are especially relevant in the context of aging societies: First, we observe different types of care systems in Europe (from family-oriented to professionally oriented), which indicates that socio-cultural dimensions and institutionalized welfare systems are important factors in structuring care systems and in dealing with the challenges of demographic aging (Haberkern and Szydlik, 2008; Haberkern et al., 2012; Schmid et al., 2012). The type of welfare system (family-oriented or state-oriented financing of elderly care) has clear effects on the distribution of care work among women and men-as a very interesting analysis by Tina Schmid (2014) illustrates. Second, the politically popular idea of crowding out family help by establishing professional care has been empirically refuted or at least put into a social context (Künemund and Rein, 1999; Künemund and Szydlik, 2009; Motel-Klingebiel et al., 2005). It becomes evident that, in demographically aging societies, intergenerational family help and care can only be sustained by supporting elderly care through qualified professional care systems (Pfau-Effinger/Grages, SOCIAL POLICY, this volume).

\section{Conclusion}

In the last twenty years-both internationally and in German-speaking countries-sociological research on demographic aging and processes of aging has resulted in a better understanding of the complex interrelationships between changing demographics and socio-political structures. Empirical and theoretical progress can be observed particularly in three relevant dimensions: First, chronological age is easily measured, but in modern societies this simple variable is losing its descriptive power. Cohort effects, lifestyle, and status indicators as well as the dimensions of health and subjective age are-at least until very late in life-much more important determinants of aging processes and aging populations than are chronological age measurements. Second, social consequences and the socio-cultural impacts of increased (disabilityfree) life expectancy on socio-political structures have been analyzed and discussed in more differentiated ways (resulting in new concepts of life phases). Third, the intergenerational dimensions of demographic aging and processes of aging have been empirically researched in much more detail. This in particular is one of the areas where sociological contributions-and contributions within German-speaking countries-have been most successful internationally. The last twenty years have resulted in a new consensus-at least among sociologists participating in this research-that the real challenge for demographically aging European societies is not demographic aging as such but a lack of social, political, and socio-political adaptation to new demographic conditions, in particular to an increased longevity of modern populations.

While research on demographic aging and aging processes has made progress, this is much less the case regarding the transfer of empirical observations and new 
concepts to political decision-making and popular perceptions of demographic aging. Deficit-oriented and simplified perceptions of demographic aging remain dominant both politically and in media discourses. This situation is reinforced by the fact that aging processes and demographic aging are still measured and defined by using traditional definitions of chronological age (for example, in defining all men and women beyond age 64 as contributing to demographic aging). New, dynamic measurements of aging have yet to be institutionalized in official demographic statistics.

\section{References}

Amann, A. Die großen Alterslügen. Generationenkrieg - Pflegechaos - Fortschrittsbremse?; Böhlau: Vienna, 2004.

Amrhein, L. Die soziale Konstruktion von 'Hochaltrigkeit' in einer jungen Altersgesellschaft. Zeitschrift für Gerontologie + Geriatrie 2013, 1, 10-15.

Bartl, W. Personalpolitik in schrumpfenden Kommunen. Ostdeutschland, Westdeutschland und Polen im Vergleich; VS: Wiesbaden, 2011.

Behrend, C. Erwerbsarbeit im Wandel, Beschäftigungschancen älterer Arbeitnehmer und Übergänge in den Ruhestand. In Erwerbsbiographien und materielle Lebenssituation im Alter; Deutsches Zentrum für Altersfragen, Eds.; Leske + Budrich: Opladen, 2001; pp 11-129.

Brandt, M. Hilfe zwischen Generationen. Ein europäischer Vergleich; VS: Wiesbaden, 2009.

Brandt, M., Haberkern, K., Szydlik, M. Intergenerational Help and Care in Europe. European Sociological Review 2009, 5, 585-601.

Brauer, K.; Clemens, W. Eds. Zu alt? Ageismus und Altersdiskriminierung auf Arbeitsmärkten; VS: Wiesbaden, 2010.

Bucher, H.; Mai, R. Bevölkerungsschrumpfung in den Regionen Europas. Zeitschrift für Bevölkerungswissenschaft 2006, 3-4, 311-344.

Clemens, W. Ältere Arbeitnehmer im sozialen Wandel. Von der verschmähten zur gefragten Humanressource?; Leske + Budrich: Opladen, 2001.

Clemens, W.; Höpflinger, F.; Winkler, R., Eds. Arbeit in späteren Lebensjahren. Sackgassen, Perspektiven, Visionen; Haupt: Bern, 2005.

Coulmas, F.; Lützeler, R., Eds. Imploding Populations in Japan and Germany. A Comparison; Brill: Leiden/Boston, 2011.

Dallinger, U. Der Konflikt zwischen familialer Pflege und Beruf als handlungstheoretisches Problem. Zeitschrift für Soziologie 1998, 2, 94-112.

Deindl, C. Finanzielle Transfers zwischen Generationen in Europa; VS: Wiesbaden, 2011.

Deindl, C., Brandt, M. Financial Support and Practical Help between Older Parents and their Middle-aged Children in Europe. Ageing \& Society 2011, 4, 645-662.

Düzgün, I.; Börsch-Supan, A.; Weiss, M. Alter und Arbeitsproduktivität - Stand der Forschung und Ausblick. In Generation 60plus - tauglich für die Arbeitswelt 2020?; Marie-Luise und Ernst Becker Stiftung, Eds.; Cologne, 2006; pp 89-95.

George, R.; Struck, O., Eds. Generationenaustausch im Unternehmen; Rainer Hampp: Munich, 2000. Graefe, S.; van Dyk, S.; Lessenich, S. Altsein ist später. Alter(n)snormen und Selbstkonzepte in der zweiten Lebenshälfte. Zeitschrift für Gerontologie + Geriatrie 2011, 5, 299-305.

Grünheid, E.; Scharein, M. G. On Developments in the Mean Joint Lifetimes of Three- and Four-Generations Families in Western and Eastern Germany - A Model Calculation. Comparative Population Studies - Zeitschrift für Bevölkerungswissenschaft 2011, 1, 41-76.

Haberkern, K. Pflege in Europa. Familie und Wohlfahrtsstaat; VS: Wiesbaden, 2009. 
Haberkern, K.; Szydlik, M. Pflege der Eltern - Ein europäischer Vergleich, Kölner Zeitschrift für Soziologie und Sozialpsychologie 2008, 1, 78-101.

Haberkern, K.; Schmid, T.; Neuberger, F.; Grignon, M. The Role of the Elderly as Providers and Recipients of Care. In The Future of Families to 2030; OECD Publishing, Eds.; Paris, 2012; pp 189-257.

Höpflinger, F. Altern und Generationen bei hoher Lebenserwartung. In Handbuch Bevölkerungssoziologie; Niephaus, Y., Kreyenfeld, M.; Sackmann, R., Eds.; Springer Fachmedien: Wiesbaden, 2016; pp 595-616.

IImarinen, J. Ageing Workers in the European Union - Status and Promotion of Work Ability, Employability and Employment; Finnish Institute of Occupational Health: Helsinki, 1999.

Isengard, B. “The Apple Doesen't Live far from the Three". Living Distances Between Parents and their Adult Children in Europe. Comparative Population Studies - Zeitschrift für Bevölkerungswissenschaft 2013, 2, 237-262.

Isengard, B. Nähe oder Distanz? Verbundenheit von Familiengenerationen in Europa; Budrich Academic: Leverkusen, 2018.

Karl, F. Das Altern der 'neuen' Alten. Eine Generation im Strukturwandel des Alters; Lit: Münster, 2012.

Kaufmann, F.-X. Die Überalterung - Ursachen, Verlauf, wirtschaftliche und soziale Auswirkungen des demographischen Alterungsprozesses; Polygraphischer Verlag: Zurich and St. Gallen, 1960.

Kaufmann, F.-X. Schrumpfende Gesellschaft. Vom Bevölkerungsrückgang und seinen Folgen; Suhrkamp: Frankfurt a.M., 2005.

Klein, T. Soziale Determinanten der aktiven Lebenserwartung. Zeitschrift für Soziologie 1999, 6, 448-464.

Klott, S. Theorien des Alters und des Alterns. In Lehrbuch Gerontologie. Gerontologisches Fachwissen für Pflege- und Sozialberufe; Becker S.; Brandenburg H., Eds.; Huber: Bern, 2014; pp 37-74.

Kohli, M. Die Institutionalisierung des Lebenslaufs, Historische Befunde und theoretische Argumente. Kölner Zeitschrift für Soziologie und Sozialpsychologie 1985, 1, 1-29.

Kohli, M.; Rein, M.; Guillemard, A.-M.; van Gunsteren, H., Eds. Time for Retirement. Comparative Studies of Early Exit from the Labor Force; Cambridge University Press: Cambridge, 1991.

Kolland, F.; Wanka A. Die neue Lebensphase Alter. In Lebensläufe im Wandel. Entwicklung über die Lebensspanne aus Sicht verschiedener Disziplinen; Wahl, H. W.; Kruse, A., Eds.; Kohlhammer: Stuttgart, 2014; pp 185-200.

Künemund, H.; Rein, M. There is more to Receiving than Needing. Theoretical Arguments and Empirical Explorations of Crowding in and Crowding out. Ageing \& Societies 1999, 1, 93-121.

Künemund, H.; Szydlik, M., Eds. Generationen - Multidisziplinäre Perspektiven; VS: Wiesbaden, 2009.

Laslett, P. A Fresh Map of Life: The Emergence of the Third Age; Weidenfeld and Nicolson: London, 1989.

Lauterbach, W. Die gemeinsame Lebenszeit von Familiengenerationen. Zeitschrift für Soziologie 1995, 1, 22-41.

Lauterbach, W. Die Multilokalität später Familienphasen. Zur räumlichen Nähe und Ferne der Generationen. Zeitschrift für Soziologie 1998, 2, 113-132.

Lindenberger, U.; Smith, J.; Mayer, K.-U.; Baltes, P. B., Eds. Die Berliner Altersstudie. 3., erweiterte Auflage; Akademie: Berlin, 2010.

Mahne, K.; Wolff, J. K.; Simonson, J.; Tesch-Römer, C., Eds. Altern im Wandel. Zwei Jahrzehnte Deutscher Alterssurvey; Springer VS: Wiesbaden, 2017.

Mayer, K.-U.; Baltes, P. B., Eds. Die Berliner Altersstudie; Akademie: Berlin, 1996. 
Motel-Klingebiel, A.; Tesch-Römer, C.; von Kondratowitz, H.-J. Welfare States do not Crowd out the Family: Evidence for Mixed Responsibility from Comparative Analyses. Ageing \& Society 2005, 6, 863-882.

Motel-Klingebiel A.; Wurm S.; Tesch-Römer C., Eds. Altern im Wandel. Befunde des deutschen Alterssurveys (DEAS); Kohlhammer: Stuttgart, 2010.

Naegele, G. Zwischen Arbeit und Rente. Gesellschaftliche Chancen und Risiken älterer Arbeitnehmer; Maro: Augsburg, 1992.

Neugarten, B. L. Age Groups in American Society and the Rise of the Young-old. Annals of the American Academy of Political and Social Science 1974, 415, 187-198.

Niephaus, Y.; Kreyenfeld, M.; Sackmann, R. Eds. Handbuch Bevölkerungssoziologie; Springer VS: Wiesbaden, 2016.

Oeppen, J.; Vaupel, J. W. Broken Limits to Life Expectancy. Science 2002, 296, 1029-1031.

Pelizäus-Hoffmeister, H. Das lange Leben in der Moderne. Wechselbeziehungen zwischen Lebensalter und Modernisierung. VS: Wiesbaden, 2011.

Puur, A.; Sakkeus, L.; Põldma, A.; Herm, A. Intergenerational Family Constellations in Contemporary Europe: Evidence from the Generations and Gender Survey. Demographic Research 2011, 25, 135-172.

Sackmann, R. Konkurrierende Generationen auf dem Arbeitsmarkt; Opladen: Westdeutscher Verlag 1998.

Sanderson, W. C.; Scherbov, S. A New Perspective on Population Aging. Demographic Research 2007, 2, 27-58.

Schimany, P. Die Alterung der Gesellschaft. Ursachen und Folgen des demographischen Umbruchs; Frankfurt a.M./New York: Campus 2003.

Schmid, T. Generation, Geschlecht und Wohlfahrtsstaat. Intergenerationelle Unterstützung in Europa; Springer VS: Wiesbaden, 2014.

Schmid, T.; Brandt, M.; Haberkern, K. Gendered Support to Older Parents: Do Welfare States Matter? European Journal of Ageing 2012, 1, 39-50.

Szydlik, M. Lebenslange Solidarität? Generationenbeziehungen zwischen erwachsenen Kindern und Eltern; Leske + Budrich: Opladen, 2000.

Szydlik, M. Sharing Lives. Adult Children and Parents; Routledge: London, 2016.

Tesch-Römer, C.; Engstler, H.; Wurm, S., Eds. Altwerden in Deutschland. Sozialer Wandel und individuelle Entwicklung in der zweiten Lebenshälfte; VS: Wiesbaden, 2006.

Unger, R. Lebenserwartung in Gesundheit. Konzepte und Befunde. In Handbuch Bevölkerungssoziologie; Niephaus, Y.; Kreyenfeld, M.; Sackmann, R., Eds.; Springer VS: Wiesbaden, 2016; pp 565-594.

van Dyk, S.; Lessenich, S., Eds. Die jungen Alten. Analysen zu einer neuen Sozialfigur; Campus: Frankfurt a.M./New York, 2009. 